\title{
Corporate Governance of SOEs and Compliance With the SOE Governance Act in Namibia: A Survey Analysis
}

\author{
Christopher P.P. Shafuda \\ University of Namibia, Department of Management Science \\ E-mail: poshafuda@gmail.com
}

Rainer Lenz

Ministry of Finance, Economic Policy Advisory Services, Namibia

Matthew Mirecki

Ministry of Finance, Economic Policy Advisory Services, Namibia

Received: Jun. 27, 2020 Accepted: Nov. 12, 2020 Online published: Dec. 3, 2020

doi:10.5296/jpag.v10i4.17251～URL: https://doi.org/10.5296/jpag.v10i4.17251

\begin{abstract}
This paper assessed the practices and standards of Corporate Governance for SOEs in Namibia. The results revealed that the state of the SOEs Corporate Governance system in Namibia is weak. SOEs are nearly uncontrolled and unmonitored regarding their Corporate Governance. Although the Government spends roughly half the size of its annual development budget on funding SOEs, it is not controlling the performance of its investments. The Namibian system of Corporate Governance is a decentralised model and relies almost solely on the Line Ministries to ensure compliance. However, the majority of Line Ministries are not executing their assigned ownership power. Most Line Ministries do not establish extra units or divisions for SOE monitoring, and instead, delegate the task of monitoring performance to staff across different divisions.
\end{abstract}

Keywords: corporate governance, state-owned enterprises, compliance, Namibia

JEL Code: H110; L250; M120; M140; M480; M510 


\section{Introduction}

Corporate governance refers to the "top management process that manages and mediates value creation for, and value transference among, various corporate claimants (including society at large), in a context that simultaneously ensures accountability towards these claimants" (Sundaram, et al. 2000: 112). Hence, It is the set of processes that determines the objectives of an organisation and keeps the organisation on the path to achieving these objectives (Mar and Young, 2001). Corporate governance for both the private and public entities has become an important topic of research in transition economies, and its importance is being recognised in different regions (Young et al. 2001; McGee, 2008; Grossi et al. 2015; Daiser et al. 2017). Shareholders and corporate managers have started to realise that there are benefits that can accrue from having a good corporate governance structure. Good corporate governance helps to increase the share price of a company and makes it easier to obtain capital (McGee, 2008) while Poor corporate governance lies at the heart of the poor performance of an enterprise (Wong, 2004).

State-owned enterprises (SOEs) play a significant role in emerging economies as they are commonly used as important instruments for public service provision (Kowalski et al., 2013; Florio, 2014), and as such good corporate governance is important if they are to succeed. Improved corporate governance tools, like a better alignment of agents' private incentives and stronger monitoring, and high-quality public governance, reduce risks such as agency risk in SOEs (Jia, et al. 2019). However, corporate governance of SOEs is a major challenge for governments (Syrett and Bertotti, 2012; Schwarting, 2013). Some Governments are not fulfilling their oversight role of ensuring the sound governance of SOEs by adopting best practices because of political intervention in the operational running of SOEs (Thomas, 2012). Political interferences have reduced performances and efficiency of the SOEs ( $\mathrm{Su}$ and $\mathrm{He}$, 2012). Poor corporate governance in the government entities has led to series of under-performances that may stem from residual welfare-provision responsibilities, and from costs of unlearning and updating structures, skill sets and procedures that became obsolete. Also, Poor corporate governance has led to corruption (He, 1998; Kwong, 1997; Shih, 1994) which further led poor moral atmosphere (moral climate, moral ethos) featuring counter-norms tolerant of improper conduct in SOEs (Jackall, 1984; Snell 2000). However, inadequate capitalisation has also contributed to poor performances of SOEs (Balbuena, 2014).

Studies have shown that most SOEs lack of efficient corporate governance and comply with the minimal governance issues outlined the legal frameworks establishing them. They also exhibit significant weaknesses in the areas of board performance evaluation, transparency and criteria for board appointment, the balance of executive directors and non-executive directors, and other board characteristics, indicating a departure from general practices (Lin, 2001; Ashipala, 2012; Simpson, 2014). Many studies have recognised the impacts of the characteristics of the board of directors (e.g. board composition and board leadership, and board size) on firm performance (Kesner and Dalton, 1985, Coulson-Thomas, 1994; Peng et al. 2003; Simpson, 2014). However, governments in emerging markets are continuously failing to recognise the importance of the board selection on the performance of SOEs. Board 
size and selection is heavily influenced by political interferences ( $\mathrm{Su}$ and $\mathrm{He}, 2012$ ).

The stakeholders' pressure on the government and enterprise leaders, however, hold the SOEs management responsible for the fair administration of the connection with groups and individuals, who have a direct effect on the enterprise (Donaldson and Preston, 1995; Freeman and Evan, 1990, p. 352). Hence, rising stakeholder expectations to improve SOEs operations and to make them strategic tools in gaining national competitiveness forced governments in many emerging countries to reform the corporate governance systems of state-owned enterprises (Parker, 1999; Dockery and Herbert, 2000). However, common problems, such as unformed regulatory systems, politicised board appointments and unclear mandates, demonstrate that considerable work still needs to be addressed to achieve durable SOE corporate governance in Africa (South African Institute of International Affairs, 2014).

Like in any other emerging market, SOEs play a significant role in the Namibian economy. However, to date, very few empirical studies have been conducted to assess their corporate governance and compliance. Indeed, this paper is perhaps the first such assessment of Corporate Governance in the Namibian SOE sector, and as such forms the building blocks for further studies on SOEs in Namibia. This paper focuses on the compliance of Line Ministries and the SOE Governance Council with the SOE Governance Act of 2006. It thus aims to assess the practices and standards of Corporate Governance for SOEs in Namibia. This is a crucial study as it provides a broad understanding of the current landscape of the SOE sector in the country. In particular, the study highlights some critical failures of the current system of Corporate Governance which must be addressed as an urgent priority before further reforms to SOEs can be undertaken.

\section{Data and Methodology}

To assess the Corporate Governance of SOEs in Namibia, a survey was undertaken jointly through the Ministry of Finance and the State-Owned Enterprise Governance Council (SOEGC) Secretariat ${ }^{1}$. Namibia had 84 SOEs at the time this survey was taken. Hence, 84 questionnaires were sent out. Questionnaires were sent out to 18 Ministries. The ministries were then asked to provide information for all the SOEs under their Votes. The questionnaire was based around the SOE Corporate Governance Act (2006) and sought to survey all Line Ministries with SOEs under their Vote as well as the SOEGC Secretariat. The results of this survey form the main body of this paper (Sections 5 and 6). Additionally, however, the study appraises from a general, theoretical perspective the critical issues associated with SOEs and Corporate Governance (Section 3) and then apply this to the case of Namibia (Section 3). The paper then presents a summary of the survey's results (Section 7). It ends with some recommendations focused on how the Corporate Governance of SOEs in Namibia might be improved.

\footnotetext{
1 The State-Owned Enterprise Governance Council (SOEGC) was established in terms of the State Owned Enterprises Governance Act, (Act No.2 of 2006) to primarily provide efficient governance of State Owned Enterprises (SOEs) on behalf of Government as the owner/shareholder, vested with concomitant powers and responsibilities for implementing an integrated governance policy framework against which to monitor compliance by SOE's. The act was amended in 2015 to turn the SOEGC in to a Ministry Public Enterprises.
} 


\section{SOEs and Corporate Governance}

\subsection{The Rationale for SOEs}

To develop a full understanding of the context of SOEs and SOE Corporate Governance, it is useful to reflect on the reasons for the existence of SOEs. Why does Namibia have a large number of SOEs, and why are their functions performed by the public and not by the private sector? Chang (2007) highlights four key market failures for which SOEs are often used as a solution to. 1) The existence of natural monopolies. State-Owned Enterprises are set up and closely regulated to prevent abuse of such a natural monopoly. 2) Capital market failures. Most notably in the case where the private sector is put off financing projects which may have high returns in the long run, due to high risks in the near term (e.g. infrastructure projects). Therefore the Government circumvents the failure of the capital market and becomes the investor by set-ting up an SOE. 3) The problem of externalities. Some projects provide a high benefit for society but are hardly profitable from a business perspective. Here it is the Government's task to invest so that the social return on investment may be captured. 4) Equity concerns. It is the responsibility of the state to create equal living conditions throughout the country. Service rendering SOEs are committed to providing services (e.g. electricity, water, etc.) all over the country, independent from business considerations. Private corporations, on the other hand, would likely only provide services to profitable areas, leaving some parts of the country - particularly poor, rural areas - without access to these services.

There are, of course, other justifications for the existence of SOEs beyond the issue of addressing market failures. For example, arguments often put forward in support of SOEs include the need to maintain a controlling interest in what are considered to be strategic industries, such as oil or a national airline, and the role they play in creating employment. All of these issues can be easily applied to the situation in Namibia. For instance, NamPower could be used as a good example of a natural monopoly, as well as addressing equity concerns by providing electricity in rural areas. TransNamib is an example of an SOE which has been established to address capital market failures and the issue of externalities, while Air Namibia can be viewed as an SOE in a strategic industry. And all of the above, plus the rest of Namibia's 84 SOEs, can be viewed as contributors to creating employment in a country where unemployment currently stands at 27 per cent, according to latest figures ${ }^{2}$.

\subsection{Corporate Governance of SOEs}

The unique reasons for the existence of SOEs make their Corporate Governance as well as unique and complex. The key complication associated with Corporate Governance is essentially the principal-agent problem. The principal is the one who provides financing or equity capital. The agent is the one who manages the company. The Corporate Governance problem here is that the principal cannot be sure that the corporate management maximises his or her interests, or if they are misusing their power to maximise their benefits. While it is true that the principal-agent problem appears in any corporate (limited corporations) where

\footnotetext{
2 Namibia Labour Force Survey 2012, NSA
} 
management and ownership (shareholders) are not identical, SOEs have some unique features as the principal is the state:

An SOE is in some ways not owned by one single owner, but by all the citizens of the country. This leads to the typical free-rider problem. No individual owner (the single citizen) has the incentive to monitor the SOE managers, as the benefit for doing so would accrue to all owners while the costs are borne by the individual who does the monitoring. Ultimately, no one feels responsible for monitoring the performance of SOEs. Also, SOEs have soft budget constraints as they can't become insolvent. SOE management knows that in a financial crisis, the Government will bail them out with taxpayers' money. This is especially the case if those SOEs have a monopoly status for basic services such as water, electricity, transport, communication etc. SOEs are backed by the Government and enjoy a kind of implicit Government guarantee. This safety net has a detrimental impact on management practices and risk appetite.

Accountability and performance in SOEs may also be hindered by the close relationship of SOE management to the political system and to the ruling party. Often SOE management positions are occupied by people who were selected due to their proximity to the ruling party rather than their management skills (Lin, 2001; Hu and Leung, 2012). Furthermore, the Government quite often has a conflict of interest between its three roles: the owner of the SOEs; the policymaker and the regulator of an industry sector. As a regulator and policymaker, the Government often makes decisions on laws and political directives which directly impact SOEs' business opportunities. This conflict of interest could be mitigated by separating the execution of ownership from the regulator and policymaker function in different institutional authorities.

Taking all above specific features of SOEs into account, it becomes clear that it is a much more challenging job for a Government to establish "good" Corporate Governance for its SOEs than it is for private shareholders in private companies. Nevertheless, SOEs should be held to higher standards of accountability than private companies as they are owned by the taxpayer (Forfás, 2010, p. 27). In this sense, the governance of the country could be benchmarked by the strength of Corporate Governance of its SOEs.

\section{SOEs and Corporate Governance in Namibia}

The following chapter explains the framework of SOE Corporate Governance in Namibia. A brief description of the number and characteristics of Namibian SOEs is followed by a documentation of the current model of SOE Corporate Governance in Namibia. Players and their responsibilities based on the SOE Governance Acts are described in detail. Finally, an overview of annual budget funds allocated to SOEs is provided.

\subsection{Classification of SOEs}

At the time of the data collection of this study, Namibia had 84 State-Owned Enterprises which are very heterogeneous in regard to their size and type of function, kind of service or 
type of business. ${ }^{3}$ According to the State-Owned Enterprise Governance Act, the State-Owned Enterprise Governance Council (SOEGC) should classify the SOEs into three categories: Regulatory enterprises, Service rendering enterprises and Economic and productive enterprises ${ }^{4}$. For the purpose of establishing remuneration levels for chief executive officers and senior managers of SOEs, and annual fees and sitting allowances for Board members, the SOEGC further classifies SOEs into three tiers, based on their revenue volume, asset size and the number of staff.
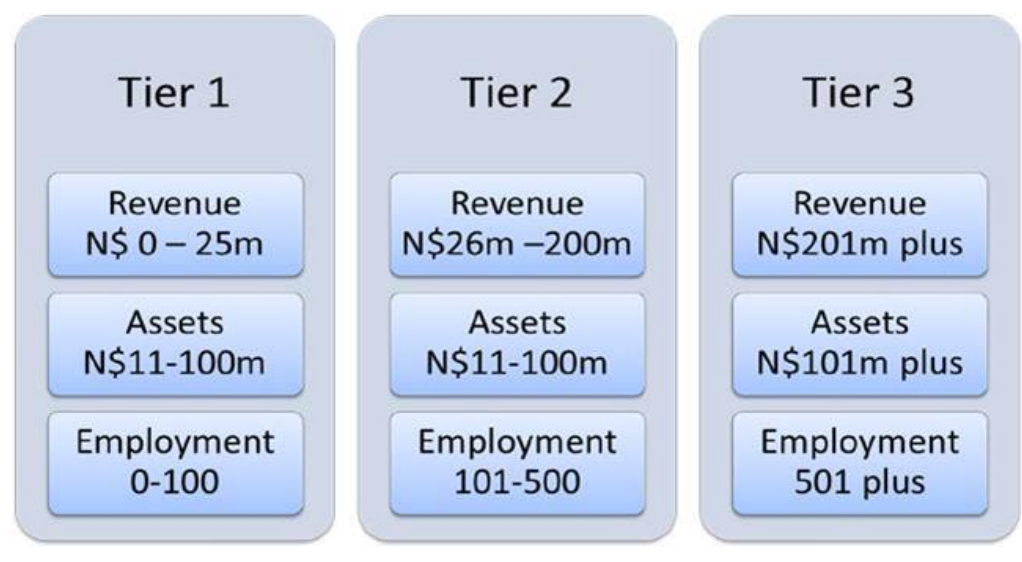

Figure 1. Classification of SOEs by Tier

Source: Deloitte (2012b, p. 12)

The classification of SOEs in Namibia has been conducted twice, in 2009 and 2011, but both times several SOEs did not respond to the data request. The official SOEGC classification was published with the Remuneration Directive in the Government Gazette August 2010 (Notice no. 174). Based on annual report data, the authors of this study attempted to update the given SOEGC data and categorise the 84 SOEs, as shown in Table 1.

Table 1. Classification of SOEs by Tier and in Type of Function

\begin{tabular}{|l|c|c|c|c|}
\hline & Economic & Regulatory & Service & total \\
\hline Tier 1 & $\mathbf{4}$ & 9 & $\mathbf{1 1}$ & 24 \\
\hline Tier 2 & 9 & 3 & 7 & 19 \\
\hline Tier 3 & 9 & 0 & 3 & 12 \\
\hline unclassified & 9 & 8 & 10 & 27 \\
\hline total & 31 & 20 & 31 & $\mathbf{8 2}$ \\
\hline
\end{tabular}

Source: Authors classification

\footnotetext{
3 The 84 SOEs include the Telecom Holding with its two subsidiaries Telecom and Post as one SOE. The same applies to the August 26 Holding Company and its subsidiaries.

${ }^{4}$ The SOE Governance Act, 2006, contains a fourth category "general enterprises", but as a sharp differentiation between general enterprises and economic and productive enterprises seemed to be difficult to make, the SOEGC classification comprises only three categories.
} 


\subsection{The Namibian Corporate Governance System for SOEs}

\subsubsection{The Namibian Ownership Model}

According to the OECD guideline on Corporate Governance, three different models of how to structure SOE ownership exist worldwide. In general, ownership can be organised in either a centralised or decentralised manner, but there also exist several combinations of centralised and decentralised models, which are categorised here as dual models (OECD, 2005, p. 23f.).

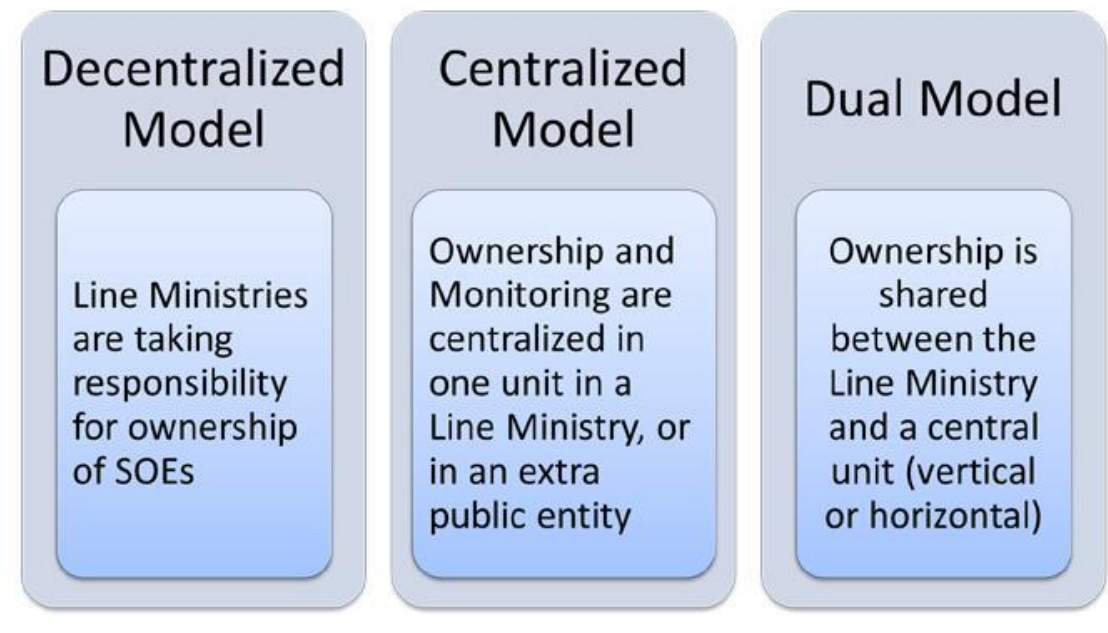

Figure 2. SOE Ownership Models

Source: OECD (2005 p. 23f)

The OECD argues in favour of adopting a centralised model:

"This approach would help in clarifying the ownership policy and its orientation, and would also ensure its more consistent implementation. Centralisation of the ownership function could also allow for reinforcing and bringing together relevant competencies by organising "pools" of experts on key matters, such as financial reporting or board nomination. In this way, centralisation can be a major force in the development of aggregate reporting on state ownership. Finally, centralisation is also an effective way to clearly separate the exercise of ownership functions from other activities performed by the state, particularly market regulation and industrial policy, as mentioned in guideline IA above.” (OECD, 2005, p. 26)

In Namibia, however, there are three parties involved in the ownership model: The SOEGC, the SOEGC Secretariat and the Line Ministries. The Namibian Model is a kind of dual model, where the Line Ministries are primarily responsible for executing ownership control, while the SOEGC is responsible for developing the political and legal Corporate Governance framework for the operation of SOEs. The administration work of the SOEGC, meanwhile, is done by the Secretariat which is located at the Office of the Prime Minister. In Namibia, in 2015, 16 Line Ministries are responsible for controlling and monitoring 82 State-owned Enterprises. 


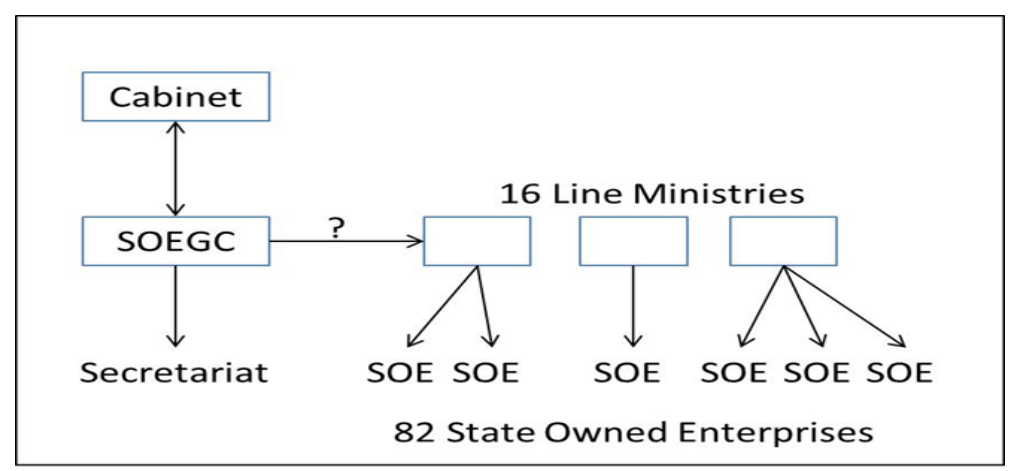

Figure 3. Ownership Structure as per SOE Act 2006

Source: Authors classification

\subsubsection{The Role of Line Ministries}

The SOE Governance Act defines the role and function of Line Ministries as follows: Section 17(1) of the SOE Act, 2006 provides for a Governance agreement to be signed between the portfolio Minister and the board of an SOE, within one month of being constituted, containing key performance indicators in terms of which the SOE's performance will be evaluated, the structure of the business and financial plan and the measure which is necessary to protect the financial soundness of the SOE. Section 18 (1) of the SOE Act, 2006 provides for a Performance Agreements have to be signed between the Minister and each board member within one month of appointing a person as a member of the board. The purpose of the Performance agreement is to monitor and assess the individual performance of the Board members against the objectives and targets set by the SOE and to see to it that the Board members conform to the code of conduct set by the enterprise as well as to Section 18 (2) and (3). Section 19(1) of the SOE Act provides that every SOE must annually at least 90 days before the commencement of its next financial year submit a Business and Financial Plan to the portfolio Minister. The Business and financial plan has to include inter alia planned objectives for the next five years and expected performance, operating budget and the capital budget for the next financial year.

The SOE Governance Act defines tasks of Line Ministries very clearly: Line Ministries have to control and monitor the financial and corporate performance of the enterprise as well as the individual performance of SOE Board members. In Governance and Performance Agreements, the Line Ministry agrees with the SOE on the fulfilment of certain performance indicators. Those indicators could be key financial indicators or technical indicators, or a mix of both, depending on whether the SOE is classified as an economic and productive, a regulatory or a service rendering SOE. Of course, only a continuous assessment of agreed performance indicators enables Line Ministries to judge the success and improvement of SOEs' performance. Monitoring and evaluation also provide a basis for accountability and transparency in the use of public resources. Knowing that the SOE's performance is closely monitored and that non-performance would have negative consequences is by itself a strong incentive for SOEs' management to comply with the SOE Governance Act and to reach performance targets. 
In Namibia, 16 Line Ministries are responsible for 82 SOEs, but SOEs are not equally distributed among the Line Ministries. Some Ministries have 8 or 9 SOEs under their Vote while others only have 1 or 2 (see Figure 4).

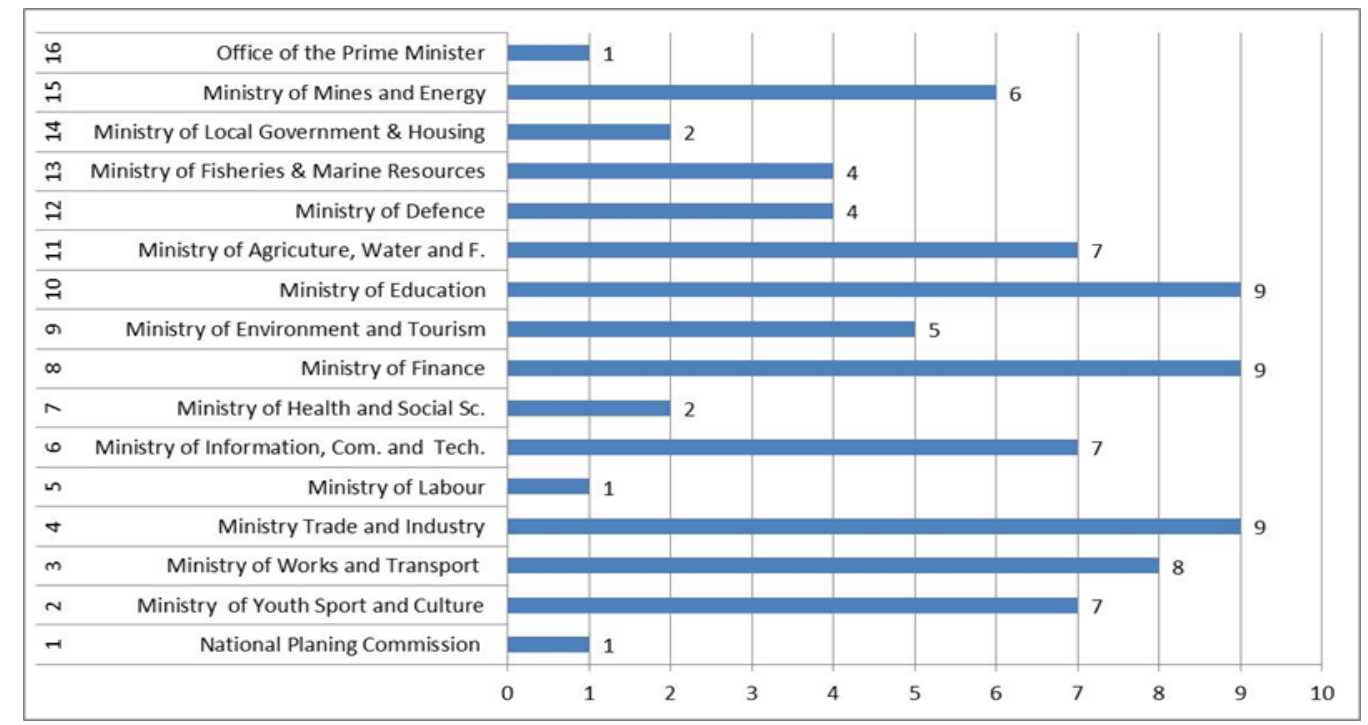

Figure 4. Line Ministries/Offices and Number of SOEs under their Vote

Source: Authors compilation

\subsubsection{Functions of the SOEGC}

The functions $^{5}$ of the SOEGC are defined in Section 4 of the SOE Act (no. 2 of 2006) to: 1) establish generally accepted common principles of corporate governance and good practice governing SOEs; 2) develop common policy frameworks for the operations of SOEs, including policy on issues relating to human resources, assets and finance; 3) determine criteria and means for the performance measurement and evaluation of SOEs; 4) lay down directives in relation to governance agreements, performance agreements, and the remuneration levels of Board members and senior executives; 5) make determinations in relation to board composition and membership; 6) Comment on annual budgets of SOEs; 7) facilitate the training and development of board member and management in corporate governance principles and practice; 8) receive and consider for approval submissions by SOEs on the annual distributions of profits and declaration of dividends in terms of section 25; 9) submit to Cabinet for decision any proposed restructuring plans for SOEs; 10) perform any other function entrusted to the Council; and classify SOEs into categories as per the Act.

Based on the SOE Act, the SOEGC has the function of setting up uniform rules, guidelines and directives for SOE governance, for the purpose of coordinating the processes between Line Ministries and SOEs, and to ensure consistency and transparency in principles of SOE governance. The SOE Act and SOEGC directives and guidelines provide a national framework for SOE governance which is important to clarify roles, duties, procedures,

\footnotetext{
${ }^{5}$ With the transformation of SOEGC in to a Ministry of Public Enterprises, functions of the SOEGC have been also consumed by the same Ministry.
} 
principles, exceptions and the rule of engagement between various key stakeholders. According to section $3 \mathrm{SOE}$ Act, the SOEGC was consists of five Government representatives, the Prime Minister, the Minister of Finance, the Minister of Trade and Industry, the Attorney General and the Director of National Planning Commission, and meets at least four times a year.

However, it is worth emphasising that the SOEGC does not monitor, nor evaluate, nor control the compliance of SOEs and Line Ministries with the given corporate governance law (the SOE Act). Implementation and enforcement of SOEGC directives and the SOE Act are solely the tasks of the respective Line Ministries. Seen from this perspective, the Namibian Model of ownership tends to be more a decentralised model as the Line Ministry is solely given the responsibility for ownership execution of SOEs. The SOEGC has no executive function in regard to ownership.

A further point to note with respect to the SOE Governance Council is its composition. Four out of the five Council members have SOEs for which they are responsible for as Line Ministers, which creates a severe conflict of interest. As previously noted, there is often a conflict of interest between the three roles Government performs with respect to SOEs - that of the owner, legislator and regulator. And while this conflict of interest could be mitigated by separating the execution of ownership from the legislative and regulatory functions in different institutional authorities, it is instead compounded in Namibia by having Line Ministers with SOEs under their Vote on the SOE Governance Council.

\subsubsection{SOEGC Secretariat}

Part III "Secretariat" of the SOE Act defines that the administration work of the SOEGC should be done by its Secretariat. 9 (1) the work incidental to the performance of the function of the Council must be performed by a secretariat consisting of administrative personnel as the Council may consider necessary. Given the fact that the Council is requested to meet only four times a year, and has a lot of different responsibilities, the majority of the Council's work has to be done by the SOEGC Secretariat.

Based on Estimates of Revenue and Expenditure for the FY2013/14 - FY2015/2016 period, the SOEGC Secretariat has the following positions budgeted for and filled at Filled at the time of the Data collection of the study.

Table 2. SOEGC Secretariat - Staffing

\begin{tabular}{|l|c|c|}
\hline Staffing & Establishment & $\begin{array}{l}\text { Filled at the time of the } \\
\text { Data collection of the study }\end{array}$ \\
\hline Permanent Secretary & 1 & 1 \\
\hline Managerial & 6 & 4 \\
\hline Chief/Control Officer/clerk & 2 & 2 \\
\hline Administrative assistant & 1 & 0 \\
\hline Secretaries/Typist & 3 & 2 \\
\hline Accounting Staff & 1 & 1 \\
\hline
\end{tabular}




\begin{tabular}{|l|c|c|}
\hline Human Resource staff & 1 & 0 \\
\hline Chief Liaison Officer & 1 & 0 \\
\hline Cleaners & 1 & 1 \\
\hline Drivers & 2 & 1 \\
\hline Sum & 19 & 12 \\
\hline
\end{tabular}

Source: Ministry of Finance, Estimates of Revenue and Expenditure from April 2013 to March 2016, p. 40.

\subsection{Budgeting for SOEs}

When looking at SOEs, the topic of Corporate Governance is closely linked to financing, as it is basically a principal-agent problem. The principal is the one who provides financing or equity capital. The agent is the one who manages the company. The Corporate Governance problem is that the principal can't be sure that the corporate management maximises his interests, or if they are misusing their power to maximise their own benefits.

In the context of SOEs, it is the state which provides the financing and capital to SOEs, which in turn gives the Government the right and the power to control and to monitor the SOE management. Therefore, financing and execution of control rights are closely linked. If the SOE management and/or board fails to meet the level of performance which has been agreed on in its Governance and Performance agreements, it should result in some form of penalty. The optimal solution would be for the execution of ownership to be in the same hands as those who make decisions regarding finance. In Namibia, the Line Ministries apply in the budget process for financing for the SOEs under their Vote. Therefore, the Line Ministries which decide upon performance indicators and enter into Governance and Performance agreements with SOEs are responsible for the budget funding of SOEs, meaning that the Namibian system concentrates the execution of ownership, monitoring and financing at the level of Line Ministries. As noted, this system efficiently and effectively addresses the principal-agent problem as it unites ownership control and finance under one authority. However, this arrangement relies totally on the execution of ownership power by Line Ministries, which means that the Ministry of Finance and Treasury do not perform a detailed appraisal of budget funding for specific SOEs since this is supposedly done by Line Ministries. This, therefore, results in weak transparency and thus, accountability in the financing of SOEs.

Namibia allocates roughly NAD4bn per fiscal year for financing SOEs. As of the current Medium-Term Expenditure Framework (MTEF) period (FY2013/14-FY2015/16), N\$12.7 billion has been budgeted for 31 of the 84 SOEs by 12 of the 16 Line Minis-tries with SOEs under their Vote (see Figure 8). The remaining SOEs and Line Minis-tries have not requested funding from central Government for the current MTEF period.

Table 3. Budget Allocations for SOE Financing (in Million NAD)

\begin{tabular}{|l|c|c|c|c|c|}
\hline Line Ministries and Offices & $\begin{array}{c}\text { SOEs } \\
\text { budgeted }\end{array}$ & $2013 / 14$ & $\begin{array}{c}2014 / \\
15\end{array}$ & $2015 / 16$ & total \\
\hline
\end{tabular}




\begin{tabular}{|l|c|c|c|c|c|}
\hline National Planning Commission & 1 & 55.90 & 51.40 & 52.00 & 159.30 \\
\hline Ministry of Youth Sport and Culture & 3 & 131.80 & 112.10 & 105.90 & 349.80 \\
\hline Ministry of Works and Transport & 5 & $1,283.10$ & 600.50 & 511.70 & $2,395.30$ \\
\hline Ministry Trade and Industry & 3 & 98.00 & 100.00 & 135.20 & 333.20 \\
\hline Ministry of Labour & 1 & 5.30 & 15.00 & 30.30 & 50.60 \\
\hline Ministry of Information, Com. and Tech. & 3 & 435.80 & 330.40 & 370.60 & $1,136.80$ \\
\hline Ministry of Finance & 3 & 445.00 & 219.00 & 15.00 & 679.00 \\
\hline Ministry of Environment and Tourism & 2 & 61.70 & 30.00 & 50.00 & 141.70 \\
\hline Ministry of Education & 6 & $2,042.30$ & $2,149.60$ & $2,695.40$ & $6,887.30$ \\
\hline Ministry of Local Government \& Housing & 2 & 130.00 & 130.00 & 150.00 & 410.00 \\
\hline Ministry of Mines and Energy & 1 & 10.70 & 10.00 & 12.00 & 32.70 \\
\hline Office of the Prime Minister & 1 & 61.50 & 63.90 & 36.20 & 161.60 \\
\hline Total & 31 & $4,761.10$ & $3,811.90$ & $4,164.30$ & $12,737.30$ \\
\hline
\end{tabular}

Source: Ministry of Finance, Estimates of Revenue and Expenditure from April 2013 to March 2016, p. 2ff.

The SOE budget funding is relatively small in relation to the total budget allocation but quite high in relation to development budget allocations (see Figure 9). As Figure 9 shows, budget allocations for funding SOEs is roughly half the size of Namibia's development budget, which emphasises that there are significant opportunity costs involved with financing SOEs.

Table 4. SOE Funding Relations

\begin{tabular}{|l|c|c|c|}
\hline Details & $2013 / 14$ & $2014 / 15$ & $2015 / 16$ \\
\hline Tot al SOEs funding (in millions NAD) & $4,761.10$ & $3,811.90$ & $4,164.30$ \\
\hline Total Budget Expenditure (in millions NAD) & $47,577.47$ & $48,215.01$ & $50,488.49$ \\
\hline SOEs Funding as\% tot al Budget Expenditure & $10.0 \%$ & $7.9 \%$ & $8.3 \%$ \\
\hline SOEs Funding as\% of Development Budget & $58.4 \%$ & $47.0 \%$ & $52.6 \%$ \\
\hline SOEs Funding as\% of GDP & $4.1 \%$ & $2.9 \%$ & $2.9 \%$ \\
\hline
\end{tabular}

Source: Ministry of Finance, Medium Term Expenditure Framework 2013/14 - 2015/16

\section{Compliance of Line Ministries With the SOE Governance Act}

In the following the results of a survey, which investigates the compliance of Line Ministries with the SOE Governance Act are documented. It starts with an assessment of the significance and relevance of the survey and continues with the documentation of results in detail.

\subsection{Non-Response, Sample Size and Significance of Survey}

Based on the initiative of the Ministry of Finance, the SOEGC Secretariat conducted a survey with Line Ministries in order to assess their compliance with the SOE Governance Act. The questionnaire contained five parts: Governance Agreements, Performance Agreements SOE's Board members, Financial \& Business Plans, Monitoring \& Evaluation, and Further remarks, comments or suggestions. 
Questionnaires were sent out to 18 Ministries $^{6}$. Only a few Ministries responded by the original deadline, and following an extension to this deadline and several reminders, the SOEGC Secretariat received responses from 13 Ministries. The non-response of the Ministry of Veteran Affairs could be excused as the War Veteran Trust Fund was incorrectly classified as an SOE. However, one could have expected the ministry to send a short memo to the SOEGC Secretariat. Taking the Ministry of Veteran Affairs out, finally 3 Ministries and 1 Office - listed below - did not respond, even after several follow-ups. Non-response of those Ministries can be evaluated as non-compliance with the SOE Governance Act as they are required to respond to any information request by the SOEGC. Indeed, it was explicitly mentioned in the questionnaire that non-response would be assumed as non-compliance with the SOE Governance Act.

Table 5. List of Ministries and Offices which did not respond

\begin{tabular}{|l|c|}
\hline Ministry or Office & \# SOEs under Vote \\
\hline Ministry of Fisheries \& Marine Resources & 4 \\
\hline $\begin{array}{l}\text { Ministry of Regional and Local Government, } \\
\text { Housing and Rural Development }\end{array}$ & 2 \\
\hline Ministry of Mines and Energy & 6 \\
\hline Office of the Prime Minister total & 13 \\
\hline
\end{tabular}

Source: Compiled by the Authors

The Ministry of Defence responded with the following statement:

"The Ministry of Defence wishes to inform you, Dear Colleague, that the reporting of information and financial statements on Defence Industries as State-Owned Enterprises, due to the nature of their confidentiality is channelled directly to the Cabinet, and nothing goes to parliament either. I wish to assure you, Dear Colleague, that the Defence Industries are run on the Principles of Good Governance and accountability. Your office should be at liberty to contact us in case of any clarity required."

It should be mentioned that the questionnaire asked solely for information about Corporate Governance, which touches on no relevant aspects of national security. The answering of a question such as whether a Corporate Governance Agreement exists for SOEs under their Vote can't be assessed as disclosure of confidential information. The Ministry of Defence has 4 SOEs under their Vote. But as the "August 26 Holdings Company" has four subsidiary companies each with its own CEO and Management Board, the Ministry of Defence should have signed 8 Governance and Performance Agreement.

Based on the non-response rate of the survey, only 11 out of 16 Line Ministries with SOEs

\footnotetext{
${ }^{6}$ Why 18 Line Ministries and not only 16 Ministries? The War Veteran Trust Fund of the Ministry for Veteran Affairs has been incorrectly classified as a SOE. After correction the Ministry of Veteran Affairs has no SOE under their vote. From the response of the Ministry of Safety and Security we learned that the Security Enterprise \& Security Officers Regulation Board is not classified as a SOE and therefore the Ministry has no SOE under its vote.
} 
under their Vote provided the responses to the questionnaires and 65 out of 82 Namibian SOEs in total. Within the figure of 65 SOEs, the Telecom Holding is counted as one entity, but as subsidiaries, Namibia Post and Telecom have their own boards and CEOs; the Ministry of Information and Communication Technology should, therefore, sign individual Governance and Performance Agreements with the holding as well as with its subsidiaries. Taking this effect into, the account sample size for the questionnaire is 67 out of a total of 84 SOEs (Telecom and Post counted as two SOEs), which equates to a participation rate of $79 \%$. Given this sample size, the results of this survey are significant and document a reliable picture of the status quo of Corporate Governance of Namibian SOEs.

\subsection{Compliance of Line Ministries}

In the following section, only aggregated results for all participating Line Ministries are documented.

\subsubsection{Governance Agreements}

Approximately one-third of SOEs have signed a Governance Agreement, but for roughly half of the 67 SOEs, there exists no Governance Agreement (the remaining 16.4\% did not respond). Governance Agreements have been in place for some minis-tries since 2010, some since 2012 and others since 2013. Three participants did not answer when Agreements had been signed, although Agreements do exist. All the 22 signed agreements contained Performance Indicators in the form of financial indicators, measuring the financial performance of the SOEs. 19 of the 22 signed Agreements contained as well as technical indicators, which measure the quality or quantity of the provided service.

Table 6. Existence of Government Agreements

\begin{tabular}{|c|c|c|c|}
\hline \multicolumn{4}{|c|}{ Government Agreement exists? } \\
\hline Number of SOEs & Yes & No & Not answered \\
\hline 67 & 22 & 34 & 11 \\
\hline $100 \%$ & $32.8 \%$ & $50.7 \%$ & $16.4 \%$ \\
\hline
\end{tabular}

Source: Compiled by the Authors

\subsubsection{Performance Agreements Board Members}

The purpose of the Performance Agreement is to monitor and assess the individual performance of Board members against objectives and targets set by the SOE. For more than $60 \%$ of the SOEs, no Performance Agreement exists, with less than one-quarter of SOEs having signed one (the remaining $15.0 \%$ did not respond).

Table 7. Existence of Performance Agreements

\begin{tabular}{|c|c|c|c|}
\hline \multicolumn{4}{|c|}{ Performance Agreement SOE Board M embers } \\
\hline \multicolumn{4}{|c|}{ Performance Agreement SOE Board Members exists? } \\
\hline Number of SOEs & Yes & No & Not answered \\
\hline 67 & 16 & 41 & 10 \\
\hline
\end{tabular}




\begin{tabular}{|c|c|c|c|}
\hline $100 \%$ & $23.9 \%$ & $61.2 \%$ & $14.9 \%$ \\
\hline \multicolumn{4}{|c|}{ Performance Agreements contain performance indicators? } \\
\hline $\begin{array}{l}\text { Number of signed } \\
\text { Performance Agr. }\end{array}$ & Yes & No & Not answered \\
\hline 16 & 11 & $\mathrm{~s}$ & 0 \\
\hline \multicolumn{4}{|c|}{$\begin{array}{l}\text { Do the performance indicators measure the individual performance } \\
\text { of Board members? }\end{array}$} \\
\hline Number of signed & Yes & \multirow{2}{*}{ No } & \multirow{2}{*}{$\begin{array}{l}\text { Not } \\
\text { answered }\end{array}$} \\
\hline Performance Agr. & & & \\
\hline 16 & 3 & 10 & 3 \\
\hline
\end{tabular}

Source: Compiled by the Authors

Performance Agreements were generally signed between 2010 until 2013, a similar range to when Governance Agreements were signed. Three ministries did not answer this question, although they indicated that Performance Agreements do exist. Majority of agreements contain Performance Indicators, but in the vast majority of cases, all Board members sign the same Performance agreement, meaning that there is no measure of the individual performance of a single Board Member. Since each Board Member has different roles and responsibilities, this arrangement fails to adequately hold Board members to account.

\subsubsection{Financial \& Business Plans}

The results reveal that 31 SOEs from 67 SOEs did not send Financial and Business Plans to their Line Minis-try, and if they do, none were sent within the requested 90 days before start of the new financial year. The majority of Financial and Business plans received included the requested information about planned objectives for the next five years and expected performance, operating budget and the capital budget for the next fiscal year. Only a few SOE receive written feedback from Line Ministries on sent Financial and Business plans.

Table 8. Financial \& Business Plans

\begin{tabular}{|c|c|c|c|}
\hline \multicolumn{4}{|c|}{ Financial \& Business Plan } \\
\hline \multicolumn{4}{|c|}{ Received Business \& Financial Plan? } \\
\hline Number of SOEs & Yes & No & Not answered \\
\hline 67 & 23 & 31 & 27 \\
\hline $100 \%$ & $34.3 \%$ & $46.3 \%$ & $40.3 \%$ \\
\hline \multicolumn{4}{|c|}{ Within 90 days before start of the new financial year? } \\
\hline $\begin{array}{l}\text { Number of received } \\
\text { B\&F Plans }\end{array}$ & Yes & $\mathrm{No}$ & Not answered \\
\hline 23 & 8 & $11^{*}$ & 4 \\
\hline \multicolumn{4}{|l|}{ Written feedback to SOE? } \\
\hline $\begin{array}{l}\text { Number of received } \\
\text { B\&F Plans }\end{array}$ & Yes & $\mathrm{No}$ & Not answered \\
\hline 23 & 10 & $11 * *$ & 2 \\
\hline
\end{tabular}


Source: Compiled by the Authors.

Note:* and ${ }^{* *}$, the authors of the study reduced the number of No-answer as the responses of two Line-Ministries have not been logical. They can't give feedback on Financial \& Business Plans, they never received.

\subsubsection{Monitoring \& Evaluation}

The monitoring and evaluation part of the questionnaire is split into four parts. The first section contains more general questions, while the remaining parts contain more specific questions concerning monitoring and evaluation of Governance Agreements, Performance Agreements and Financial and Business plans.

\subsubsection{General}

9 out of 11 Ministries (excluding NPC) from the sample answered the question concerning the number of staff used for monitoring and evaluation. Two Ministries, those responsible for Labour and Agriculture, currently have no staff for SOE monitoring. The Ministry of Agriculture, Water and Forestry wrote the following comment:

- The Ministry of Agriculture, Water and Forestry in it is current structure does not have a division responsible for monitoring and evaluation of its SOEs. However, the ministry has made a provision of an $M \& E$ section in its new stricture, which is currently with the office of the prime minster for approval. Once the new structure is approved, the directorate of planning will be responsible for monitoring and evaluation of SOE taking in account the governance agreement and the specific performance agreements signed between the SOE and the ministry. Provision is made for four (4) staff members under the M\&E section who will be recruited in a full-time basis.

- $\quad$ The monitoring of SOEs compliance to key performance indicators will be enforced once the new structure is implemented. The ministry will record the monitoring of SOEs compliance with key performance indicators as stipulated in the government agreement. The ministry envisaged to carry out the monitoring on a quarterly basis as it is currently done for the ministerial development projects

Table 9. General Monitoring and Evaluation

\begin{tabular}{|l|c|c|c|}
\hline \multicolumn{5}{|l|}{ M\&E General } \\
\hline How many members of staff dedicate time to M\&E of SOEs? \\
\hline Ministry & No. of SOEs & No. of Staff & Full-time/Part-time \\
\hline NPC & 1 & N/A & N/A \\
\hline Youth, Sport \& C. & 7 & 4 & Part-time \\
\hline Works \& Transport & 8 & 2 & Part-time \\
\hline Trade and Industry & 9 & 3 & Full-Time \\
\hline Labour & 1 & None & None \\
\hline Health and Social Sc. & 2 & 2 & Part-time \\
\hline Finance & 9 & 2 & Full-t im e \\
\hline
\end{tabular}




\begin{tabular}{|c|c|c|c|}
\hline Environment and $\mathrm{T}$. & 5 & 5 & Full-time \\
\hline Education & 9 & 4 & Full-time \\
\hline Agriculture, Water & 7 & None & None \\
\hline $\begin{array}{l}\text { No. of Ministries } \\
\text { monitoring }\end{array}$ & $\begin{array}{l}\text { No. of SOEs } \\
\text { monitored }\end{array}$ & $\begin{array}{l}\text { No. of Staff } \\
\text { Full- time }\end{array}$ & $\begin{array}{l}\text { No. of Staff } \\
\text { Part-time }\end{array}$ \\
\hline 7 & 49 & 12 & 8 \\
\hline
\end{tabular}

Source: Compiled by the Authors

The Results can be summarised that 12 full-time staff and 8 part-time staff are employed across 7 Ministries to monitor and evaluate 49 SOEs. If 2 part-time workers are count-ed as one full-time staff, then 16 full-time staff are employed for 49 SOEs. This in turn leads to a ratio 0.33 staff time per SOE. Having 84 SOEs in Namibia (taking Telecom and Post each as one SOE) the monitoring done by Line Ministries would require 27.5 full-time staff. However, this calculation is not entirely correct as it assumes that the time needed to monitor one SOE is always same. That is not the case as one could assume that as people gain experience and standardise their approach, so the monitoring time per SOE could be expected to decrease. Furthermore, some SOEs are likely to be more complicated to evaluate than others, perhaps due to their size or structure.

\subsubsection{Governance Agreements}

22 SOEs responded that their Line Ministry monitors their compliance with key performance indicators for Governance Agreements. This is consistent with answers in Part A of the questionnaire asking about the existence of Governance Agreements. However, the results of M\&E of Governance Agreements are recorded in a database for only 9 of the 22 monitored SOEs, while Ministries indicated that standard procedures were in place if SOEs fail to reach the agreed performance indicators (and that those procedures are written into Governance Agreements) for only 2 SOEs. The 2 'yes' answers were given by the National Planning Commission for the one SOE under their Vote, and by the Ministry of Health.

Table 10. Monitoring and Evaluation of Governance Agreements

\begin{tabular}{|c|c|c|c|}
\hline \multicolumn{4}{|c|}{ M\&E Governance Agreements } \\
\hline \multicolumn{4}{|c|}{$\begin{array}{l}\text { Monitoring of compliance with key performance indicators for Governance } \\
\text { Agreements? }\end{array}$} \\
\hline Number of SOEs & Yes & No & Not answered \\
\hline 67 & 22 & 26 & 19 \\
\hline $100 \%$ & $32.8 \%$ & $38.8 \%$ & $28.4 \%$ \\
\hline \multicolumn{4}{|c|}{ It this monitoring recorded (e.g. in excel etc.) or rather done on an ad hoc basis? } \\
\hline Number of monitored SOEs & Yes & No & Not answered \\
\hline 22 & 9 & 7 & 6 \\
\hline \multicolumn{4}{|c|}{$\begin{array}{l}\text { What happens if the SOE fails to reach the agreed performance indicators? } \\
\text { Procedures in place for the line Ministry to follow in response to } \\
\text { failures? }\end{array}$} \\
\hline
\end{tabular}




\begin{tabular}{|c|c|c|c|}
\hline Number of monitored SOEs & Yes & No & Not answered \\
\hline 22 & 2 & 12 & 8 \\
\hline \multicolumn{4}{|c|}{ Are these procedures written into Governance Agreements with SOEs? } \\
\hline Number of monitored SOEs & Yes & No & Not answered \\
\hline 22 & 2 & 14 & 6 \\
\hline
\end{tabular}

Source: Compiled by the Authors

\subsubsection{Performance Agreements}

Results for the monitoring and evaluation of Performance Agreements are comparable to those given for Governance Agreements. Ministries indicated that they monitor the compliance with Performance Agreements for 15 SOEs. Again, this answer is consistent with results concerning the existence of Performance Agreements in part B of the questionnaire. Meanwhile, Ministries record the results of M\&E of Performance Agreements for 8 SOEs. Only the National Planning Commission and Ministry of Health and Social Sciences have installed standard procedures - and have communicated those procedures by writing it into Performance Agreements - in the case that the SOE's management or board fails to reach their performance indicators.

\subsubsection{Financial and Business Plans}

Except for in the Ministry of Finance, all of the other 6 Ministries have staff spread across different departments responsible for the monitoring and evaluation of Financial and Business plans, or in other words, that there is no single unit in the Ministries (be-sides in the Ministry of Finance) responsible for the M\&E of Financial and Business plans. Based on this information, one can assume that there is no standardised and uniform approach to monitoring and evaluating of SOEs' Financial and Business Plans, and neither across the Ministries nor within any one Ministry itself. However, standardisation would lead to an increase in professionalism, quality and efficiency.

\subsubsection{Further Remarks, Comments or Suggestions}

This section only incorporates comments and remarks which are closely related to the preceding issues. All other remarks provided by respondents are documented in Annexes.

Of note are the following comments:

\section{Ministry of Labour}

- The social security commission M\&E was mainly between the board and management. Identified failures were mainly rectified between the board and management.

\section{Ministry of Information, Communication and Technology}

- No specialised expertise to assist ministry staff to facilitate draft of agreements. A request to appoint a consultant was not approved in 2013.

- General lack of staff expertise to handle Government Issue - No dedicated unit or specifically assigned to handle governance issues.

- Insufficient funds to professionally handle the activity. 


\section{Ministry of Health and Social Science}

- The coordination of the induction of all council members is crucial to strengthening the governance of the SOE

- A forum for the SOEs is crucial for the sharing of the best practices and in-creasing cooperation among SOEs

\section{Ministry of Finance}

- Capacity is limited; there are very little qualified technical/expertise interest in government positions

- A system that can attract financial specialists to work with the monitoring and evaluation of SOEs is extremely encouraged.

\section{Ministry of Environment and Tourism}

- The supervision of the State-owned enterprises within the ministry needs improvement

- The ministry has identified the supervision of SOEs as one of its priorities during this annual plan

- According to the plan, all SOEs must have a Governance Agreement and a Performance Agreement signed and a Financial and Business plan submitted by the end of the second term of 2014/15, to enable the ministry to monitor and evaluate performance.

\section{Compliance of SOEGC and its Secretariat}

To complete the overall picture of SOE Corporate Governance in Namibia, the Ministry of Finance also designed a questionnaire for the SOEGC Secretariat about its own compliance with the SOE Governance Act. The questionnaire was sent to the SOEGC Secretariat in mid-November 2013, but unfortunately, the Secretariat was not able to complete the questionnaire before February, despite several follow up calls. Therefore, not all of the following information is first hand from the SOEGC Secretariat itself, but rather relies on newspaper articles and a report written by Deloitte (2012a) from 2012.

The SOE Governance Council and the SOE Governance Council Secretariat have to be seen as a single functional unit, as it would not be fair in regards to compliance to differentiate between the Secretariat and the Council. The role of the Secretariat is just to assist the Council in its tasks by doing the administrative work. The performance of the SOE Governance Council and its Secretariat shall be measured against the objectives and responsibilities defined in the SOE Governance Act, specifically whether they have been met.

Table 11. Compliance of Council and Secretariat with SOE Governance Act

\begin{tabular}{|l|l|l|}
\hline & Objective/Responsibility/Task & \multicolumn{1}{c|}{ Status } \\
\hline 1 & $\begin{array}{l}\text { Establish generally accepted common } \\
\text { principles of corporate governance and } \\
\text { good practice governing SOEs }\end{array}$ & $\begin{array}{l}\text { Report on Corporate Governance } \\
\text { guidelines for SOEs has been done, but } \\
\text { those guidelines have not been adopted } \\
\text { by Cabinet and are not released as } \\
\text { common principles }\end{array}$ \\
\hline 2 & Develop common policy frameworks & Included in Corporate Governance \\
\hline
\end{tabular}




\begin{tabular}{|c|c|c|}
\hline & $\begin{array}{l}\text { for the operations of SOEs, including } \\
\text { policy on issues relating to human } \\
\text { resources, assets and finance }\end{array}$ & $\begin{array}{l}\text { guidelines but did not become a com- } \\
\text { mon policy framework as the Cabinet } \\
\text { has not adopted those guidelines }\end{array}$ \\
\hline 3 & $\begin{array}{l}\text { Lay down directives in relation to } \\
\text { governance agreements, performance } \\
\text { agreements and the remuneration levels of } \\
\text { Board members and senior executives }\end{array}$ & $\begin{array}{l}\text { Yes - Remuneration Directive Gov. Not } \\
174 \text { of } 12 \text { August 2010; } \\
\text { No - Directive on Governance and } \\
\text { Performance Agreement, only templates for } \\
\text { Agreements are designed and provided to Line } \\
\text { Ministries }\end{array}$ \\
\hline 4 & $\begin{array}{l}\text { Determine criteria and means for the } \\
\text { performance measurement and evaluation } \\
\text { of SOEs }\end{array}$ & None \\
\hline 5 & $\begin{array}{l}\text { Make determinations in relation to } \\
\text { board composition and membership }\end{array}$ & $\begin{array}{l}\text { Advisory role; not in accordance with } \\
\text { SOE Act; section } 15 \text { appointments not } \\
\text { effective yet }\end{array}$ \\
\hline 6 & Comment on annual budgets of SOEs & None \\
\hline 7 & $\begin{array}{l}\text { Facilitate the training and development } \\
\text { of board member and management in } \\
\text { corporate governance principles and } \\
\text { practice }\end{array}$ & None \\
\hline 8 & $\begin{array}{l}\text { Receive and consider for approval } \\
\text { submissions by SOEs on the annual } \\
\text { distributions of profits and declaration } \\
\text { of dividends in terms of section } 25\end{array}$ & None \\
\hline 9 & $\begin{array}{l}\text { Submit to Cabinet for decision any } \\
\text { proposed restructuring plans for SOEs }\end{array}$ & None \\
\hline 10 & $\begin{array}{l}\text { Classify SOEs into categories as per } \\
\text { the Act }\end{array}$ & $\begin{array}{l}\text { Classification is done } 2009 \text { and } 2011 \text {, } \\
\text { Directive } 12 \text { August } 2010\end{array}$ \\
\hline
\end{tabular}

Source: Deloitte (2012a, p. 21)

Table 11 paints a picture of very poor performance by the SOEGC and its Secretariat, only fully completing one task since 2006 - that of SOE classification (task 10). In addition, the SOEGC and its Secretariat have partially completed a further three tasks (tasks 1, 2 and 3).

It could be argued that the limited number of experts employed in the SOEGC could go some way towards explaining the weak performance of the Council and the Secretariat. For example, only 4 out of 6 management positions are currently filled. However, this can only partially explain the failure of the SOEGC and its Secretariat in fulfilling its mandate. Most of its tasks are unique work orders that do not require constant monitoring, and as such, such work could easily be outsourced to external consultants. Indeed, this happened with the SOE classification and the remuneration Directive, which were both completed by Deloitte. Therefore, the SOEGC Secretariat needs only to have the management capability necessary to commission and to monitor consultancies, which it clearly does, given that this has been 
done on two occasions. The Secretariat's failure to do this for more of its mandated tasks, therefore, appears to be a result of management staff simply failing to adequately do their jobs.

The Secretariat, however, is only the administrative arm of the Council, and therefore can't be made responsible for its failure. The SOE Governance Act delegates all responsibilities directly to the Council, so the Council is the main body which should be kept accountable for the poor performance. The Council has to delegate the tasks to the Secretariat and to monitor whether the Secretariat performs the tasks assigned.

\section{Summary of results and conclusion}

The overall state of the Namibian SOE Corporate Governance system is weak. The 84 Namibian SOEs are nearly uncontrolled and unmonitored in regard to their Corporate Governance. The Government spends nearly half the size of its annual development budget on funding SOEs without controlling the performance of its investments.

The Namibian system of Corporate Governance is a decentralised model and relies almost solely on the Line Ministries to ensure compliance. However, the majority of Line Ministries are not executing their assigned ownership power. More than 50\% of Line Ministries have neither signed Governance nor Performance Agreements with the SOEs under their Vote. Most SOEs don't inform their Line Ministries about their financial situation and their investment plans on a regular basis. Without receiving Financial \& Business Plans, the Line Ministries effectively are lacking any data to measure the performance of SOEs. Nevertheless, they do the budgeting for their SOEs. The question must be asked: How can they adequately budget for SOEs if they don't know what is going on?

Despite the fact that Line Ministries are not effectively executing the state's shareholder rights, they need lots of full-time staff for this task. Most Line Ministries don't establish extra units or divisions for SOE monitoring, and instead, delegate the task of monitoring performance to staff across different divisions. There is no consistency in implementation and uniformity in the monitoring of SOEs, as every Line Ministry is per-forming this task differently. Further, by spreading staff both across and within Line Ministries, the benefit of having a pool of financial, legal and accountancy experts concentrated in a single unit is being missed out on. Additionally, the costs of bundling so many experts across 16 different Line Ministries for the monitoring of only a few SOEs under their Vote are much too high; having 82 SOEs reporting to 16 Line Minis-tries/Offices and 16 Line Ministries/Offices reporting to the SOEGC or to Cabinet on State Ownership makes information sharing much more costly, and is also likely to impede the quality of information. Finally, there could be a conflict of interest between the Line Ministry's task to regulating and developing a particular industry and the monitoring of an SOE operating in this sector.

A further failure of the Corporate Governance system in Namibia is the weakness of the SOEGC and its Secretariat. The function of the Council is to set up uniform rules, guidelines and directives for SOE governance for the purpose of coordinating the process between Line Ministries and SOEs. However, the SOEGC has no mandate to control the Line Ministries in 


\section{Macrothink}

their ownership execution. Furthermore, the Council and its

Secretariat has failed to fulfil most of these tasks. As a result, Line Ministries are operating in a vacuum without receiving any orientation. Neither common principles of Corporate Governance nor common policies frameworks for the operations of SOEs, including policy on issues relating to human resources, assets and finance exist.

\section{Recommendations}

\subsection{Centralised SOE-Monitoring and Evaluation Unit}

It is felt that the current structure for monitoring and evaluating SOEs and ensuring their compliance with appropriate Acts and Laws is inadequate. The decentralised system presently employed in Namibia means that there is no consistency in the approach to the monitoring and evaluating SOEs and that the personnel used to do so are spread across a number of Ministries and departments to the detriment of efficiency and efficacy of monitoring and evaluation. Further, it is suggested that the current system has too many stakeholders, which has the result of making the reporting channels and roles and responsibilities of each institution confusing and unnecessarily bureaucratic, also at the cost of efficiency and efficacy of monitoring and evaluation, as well as at the cost of implementation and enforcement.

Against this background, therefore, it is strongly recommended that a centralised unit is established with the task of monitoring and evaluating the performance of SOEs, as well as ensuring compliance with appropriate Acts and Laws. This will not only help to streamline and clarify the process of monitoring and evaluating SOEs but will also concentrate skilled professionals within a single organisation to take advantage of economies of scale and thus reduce costs and improve efficiency.

The proposed structure is based on the Crown Ownership Monitoring Unit (COMU) in New Zealand and Temasek Model in Singapore, where a centralised unit - based in the Treasury monitors the performance of SOEs and provides advice to Line Ministries on SOE performance, but the Board and management of the SOE remains accountable to the responsible Line Ministry. 


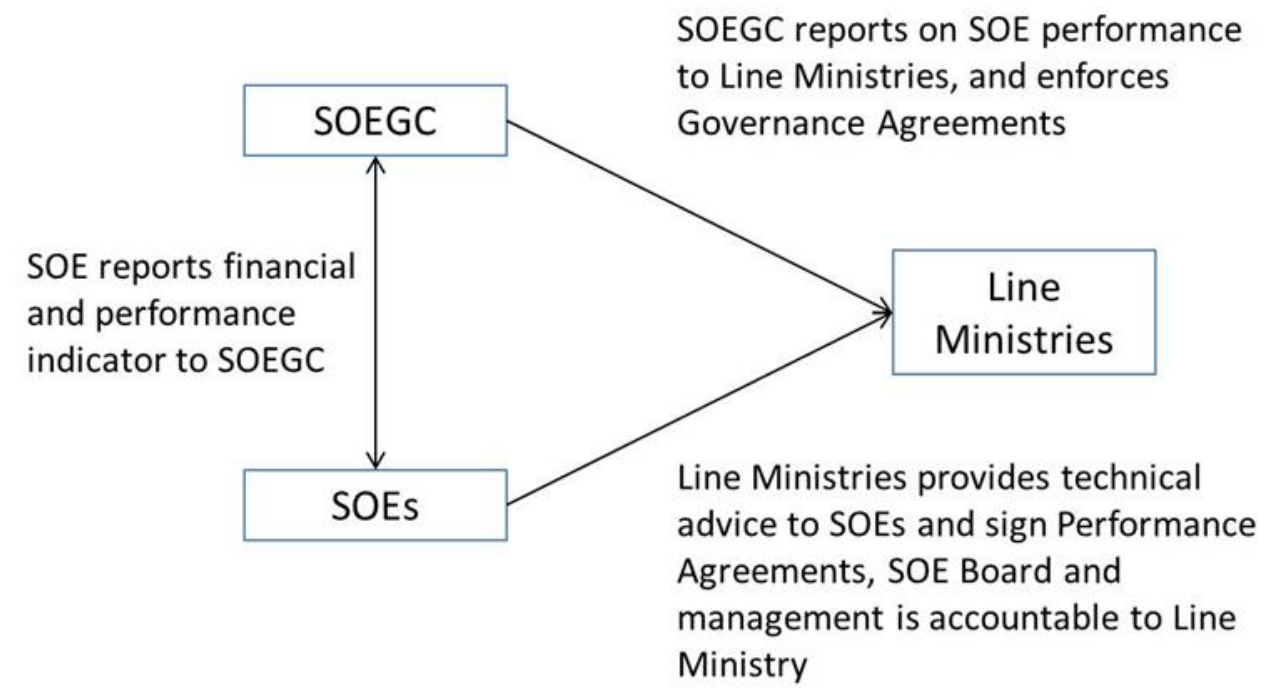

Figure 5. Proposed Reporting Structure for SOEs

Source: Compiled by the Authors

Adapting this system to the context of Namibia, it is recommended that that SOEs report directly to the SOEGC, which will take sole responsibility for monitoring and evaluating the performance of SOEs and will subsequently provide advice to Line Ministries on SOE performance. The SOEGC will also take responsibility for enforcing Governance Agreements. The responsibility of the Line Ministry is therefore limited to providing technical assistance to SOEs and enforcing Performance Agreements, as the Board and management of the SOEs remain accountable to the Line Ministries. An added benefit of this structure is that the current inherent conflict of interest between the Government's three duties as legislator, regulator and owner is addressed since the three tasks will now be divided among three separate, independent institutions.

However, for this system to be effective, the SOEGC Secretariat (Ministry of SOEs) must be restructured. It is recommended that the proposed centralised unit will take the form of a new or revamped directorate within the SOEGC, with the following structure ${ }^{7}$

\footnotetext{
${ }^{7}$ This proposed structure has been adapted from Deloite (2012a), p25
} 


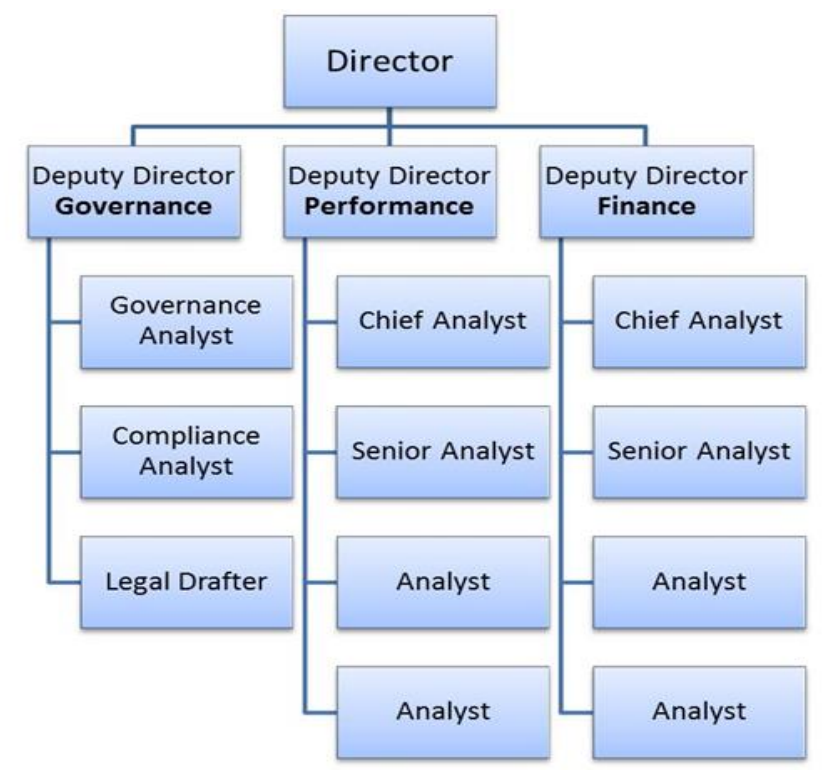

Figure 6. Proposed structure for Central SOE unit

Source: Compiled by the Authors

This proposed structure divides the task of monitoring and evaluating SOEs into three distinct divisions: Governance, Performance and Finance. While the exact job descriptions for each position within the proposed structure would still need to be finalised, the general idea is for specialised personnel to be recruited to ensure that monitoring, and perhaps more importantly evaluation, are performed to the requisite standard. This would, therefore, mean ensuring that Analysts employed in the Finance division, for example, have the required training and experience in reading and interpreting balance sheets and calculating and analysing financial ratios, etc.

\subsection{Efforts to Increase Accountability}

A second shortcoming of the current system for monitoring and evaluating SOEs and ensuring their compliance with appropriate Acts and Laws is that it fails to promote accountability. At present, there are very few tangible repercussions if SOEs fail to hit their performance targets, which mean that there is very little incentive for the management and Boards of SOEs to improve the performance of the organisations they are responsible for.

This is in part due to the principal-agent problem, in so far as absent the principal-agent problem, there are built-in accountability mechanisms such as the enterprise failing and going bankrupt. However, this is not to say that other methods of improving accountability don't exist.

It is strongly recommended that Governance and Performance Agreements should be linked to remuneration packages of management and Board members of SOEs. Withholding funding from an SOE for failure to meet performance targets ultimately has a negative impact upon the end-user and moreover fails to adequately discipline those who are responsible. Therefore, a more appropriate punishment for failing to adhere to Governance and Performance 
agreements would be to link remuneration packages of management and board members of SOEs to the fulfilment of performance indicators. That is, if the SOE fails to meet its performance targets, management and Board members do not receive a bonus. Remuneration packages in this context should be heavily weighted towards bonuses (i.e. should have a fairly low base salary, but a high overall salary should target be met) so as to encourage management and Board members to improve corporate performance.

\subsection{Criteria for New SOEs and Review of Existing SOEs}

The existence of an SOE must be justified in two ways: On the one hand, there must be good reasons why the job is done by a state-owned company and not by a private sector company. As explained previously (see page 4), a state-owned enterprise may be justified in a market economy only where there is a potential market failure. This risk of market failure must be described in detail in the creation of the SOEs, and over the years a Commission should regularly review whether the risk still persists and thus the existence of the SOE is still justified. On the other hand, the Government must be able to explain what the advantage is of the task being performed by an independently operating SOE instead of civil servants within a Line Ministry. Why is the job outsourced from a Minis-try to an SOE? Outsourcing from public administration might make sense for two reasons: (1) The avoidance of a conflict of interests for the Government be-tween the task of legislator and regulator and the task of operating a service provider; and (2) An increase in efficiency and in professionalism. However, this argument needs to be backed by cost calculations. Furthermore, one might ask the question why the ministry administration is so much less effective and professional compared to an independent SOE. These too must be described in detail in the creation of the SOEs, and over the years a Commission should regularly review whether the original rationale for creating the SOE is still justified.

The current problems of Corporate Governance of SOEs are also the result of the large number of existing SOEs. Of course, it would be easier to control 20 or 30 SOEs than 84 SOEs. However, it seems that SOEs are mushrooming in Namibia as the number of SOEs continues to increase. Yet, it is not just the number of SOEs; the budget spending for SOEs is also increasing. In FY2006/07, money transfers from Government to SOEs were just under N\$1 billion, having increased from just N\$102 million in FY1993/94. In FY2011/12, however, that figure had increased to $\mathrm{N} \$ 1.4$ billion, while the current MTEF period estimates a further $\mathrm{N} \$ 4.5$ billion for SOEs over the next three fiscal years. It is, therefore, time to cap the number of SOEs, or even to reduce it.

The SOE Governance Act should be updated to include a chapter about the establishment of SOEs. It should define exactly when it is appropriate to found an SOE and when it is not. Furthermore, the amended Act should request the development of standard procedures for the establishment of SOEs. The standards for founding an SOE should request that new SOEs have to register under the Companies Act, and are not created under an individual statute. Meanwhile, those SOEs which have been born of an individual Act should be reregistered under the Company Act, and the Act/statute should be abolished. By doing so, SOEs will be forced to operate under the same law as private companies, without any differences. 
Additionally, the amended Act should request a central body to assess the justification for new and existing SOEs. Every 2-3 years, all SOEs should be reviewed to assess whether the original reason for founding them still applies.

These are recommendations similarly made by Forfás (2010) who in analysing the in Irish SOE sector notes:

"One stringent example is the German budget law which requires the Government to examine and put forward a positive argument for the companies to be retained in State ownership. This process is required every 2 years and the automatic commencement of privatisation follows if the case for continuation of state ownership is not accepted in the budget bill. Therefore, in theory there is no difference between arguing for the creation of new SOEs and the continuation of existing SOEs. Such a requirement logically needs to be backed by standardised evaluation criteria and processes. The UK takes a similar approach to the question of whether continued state ownership of companies is justified rather than proceeding on a status quo basis."

\subsection{Transparency and Disclosure Policy}

SOEs belong to all citizens of the country. Taking this into account, the Government should publish annual accountability reports on SOE performance, budget funds used for SOEs, financial guarantees etc. for public dissemination. A website should list all SOEs with financial statements available for download. Salaries of CEOs and Board members should be published. Public opinion and the press are sometimes the best control of Government and its SOE policy, and often much better than opposition parties in parliament. SOEs themselves should be subject to annual independent external audit based on international standards. The existence of specific state control procedures does not substitute for an independent external audit OECD (2005, p. 16)

\subsection{SOE Financing}

It has been proposed that a system of pooled funding be established to help finance SOEs. The recommend involved system earnings from profitable SOEs subsidising SOEs which run a deficit, with the rationale being that this would help to ease the burden on the central budget of funding SOEs. However, this thinking is severely flawed. Not only does it not encourage failing SOEs to become more productive, but it actually discourages well-functioning SOES from maximising their efficiency. If failing SOEs know that they will be subsidised by profitable SOEs, there is no reason for them to improve. Meanwhile, if profitable SOEs know that their profits will go towards bailing out underperforming SOEs, there is no longer any reason for them to perform well - it is far easier for them to fail and simply receive a transfer from another SOE.

That said, there is a need to reform the current system of financing SOEs. Firstly, there it is essential that the budgeting process for SOEs is overhauled. Currently, Line Ministries assess the funding needs for the SOEs under their Votes, which are then submitted to the Ministry of Finance. However, this system means that the Ministry of Finance - which has ultimate 
responsibility for allocating State funds - never has the opportunity to assess for themselves the budget requests from SOEs. This highly opaque and unaccountable system is both inefficient and costly.

It is recommended that assessments of SOE funding requests are performed by the Finance division in the newly formed central unit. Strict guidelines should be established for doing so, including the stipulation that SOEs must submit current audit-ed financial statements. Failure to do so should result in a penalty, such as a remunerative penalty for the management and/or Board of the SOE in addition to a freeze on funding from central Government, for example, capping transfers equal to the previous year. Although this has the potential to negatively impact the end-user, a more accountable and transparent budgeting system is essential. Indeed, without better monitoring and evaluation of SOEs, it is impossible to determine whether end-users are being negatively impacted, and if so, to what extent.

Beyond this, the current Government cash management system is lacking efficiency. Funds budgeted for Line Ministries and SOEs are paid at the beginning of every quarter to the ministry, which deposits the money in a commercial bank account. The banks subsequently use these deposits for investing in Government Treasury Bills. Remuneration of deposits is much lower than the interest banks receive from buying Treasury Bills. This system makes commercial banks rich on the back of taxpayer's money.

What the commercial banks are doing in this example, is acting as an intermediary which collects deposits from public entities on the liability side and lends to public entities on the asset side, could be easily done by a Government institution itself. Namibia could follow the South African example to found a "Corporation of Public Deposits", which is the transaction platform for money market investments within the public sector. Bank of Namibia would support such a public intermediation model as the money is kept within the domestic public sector, which in turn reduces the risk of capital exports to SA. This system essentially introduces the idea of pooled funding, but makes it optional rather than compulsory, and therefore eliminates the negative repercussions associated with the original pooled funding system. However, a precondition for such a finance facility is to know exactly the credit risk of every SOEs participating in such a system. Therefore the financing solution comes only after the implementation of the above described SOE Corporate Governance reforms.

\section{Study Implication}

It is strongly encouraged that the results and recommendations presented in this paper form the basis for any discussions on how the SOE sector in Namibia and other developing countries can be reformed. The results of this study suggest that the sector is in desperate need of reform and that this must begin with addressing the myriad weaknesses in Corporate Governance. It is also recommended that further empirical studies are conducted to build on the work presented here. Evidence-based policymaking must be made a priority, but for this to happen, the evidence must first be produced. To this end, empirical studies such as this paper are vital. 
Note:

The State-owned Enterprises Governance Act of 2006 amended in 2015 to replace the State-owned Enterprises Governance Council with the Minister responsible for public enterprises and creation of the ministry of public enterprises to provide for incidental matters. Hence, the responsibilities of the Council were all transferred to the Minister responsible for public enterprises. Furthermore, the Public Enterprises Governance Act of 2019 was promulgated in 2019. However, the Act still gave so much power to the Line Ministers ${ }^{8}$ to interfere on SOEs' operations. Hence, the risk of political interference on the SOEs operation still exists. Therefore, this study is still relevant since nothing much has changed on the SOEs governance.

\section{Disclosure Statement}

This study was not funded, and there are no conflicts of interest.

\section{References}

Ashipala, S. N. (2012). An analysis of corporate governance within the framework of state owned enterprises governance act in Namibia with specific focus on Namwater, Nampower and Transnamib. MBA Dissertations. Retrieved from http://hdl.handle.net/10019.1/21195

Balbuena, S. S. (2014). State-owned enterprises in Southern Africa: A stocktaking of reforms and challenges. OECD Corporate Governance Working Papers, No. 13, OECD Publishing, Paris. https://doi.org/10.1108/03090599410062516

Chang, H. J. (2007). State-owned enterprise reform. UN DESA. Policy note.

Coulson-Thomas, C. (1994). Developing Directors: Building an Effective Boardroom Team. Journal of European Industrial Training, 18(6), 29-52.

Daiser, P., Ysa, T., \& Schmitt, D. (2017). Corporate governance of state-owned enterprises: a systematic analysis of empirical literature. International Journal of Public Sector Management, 30(5), 447-466. Retrieved from https://doi.org/10.1108/IJPSM-10-2016-0163

Deloitte. (2012a). Effective Oversight, Structure and KRAs for the SOEGC Secretariat Finanl Report to SOEGC.

Deloitte. (2012b). SOE Governance Report on the classification of SOEs Final Draft for Submission to SOEGC, 1-23. Windhoek, Namibia.

Dockery, E., \& Herbert, W. E. (2000). Corporate governance and enterprise restructuring in transition economies: evidence from privatised Polish companies. Managerial Finance, 26(9), 80-92. https://doi.org/10.1108/03074350010766891

Donaldson, T., \& Preston, L. E. (1995). The stakeholder theory of the corporation: Concepts, evidence, and implications. Academy of management Review, 20(1), 65-91. https://doi.org/10.5465/amr.1995.9503271992

\footnotetext{
${ }^{8}$ Line Minister/Ministry is the Ministers/Ministry responsible of the overseeing the operation and governance of an SOE.
} 
Florio, M. (2014). Contemporary public enterprises: innovation, accountability, governance.

Journal of Economic Policy Reform, 17(3), 201-208. https://doi.org/10.1080/17487870.2014.913823

Forfás, I. (2010). The Role of State Owned Enterprises: Providing Infrastructure and Supporting Economic Recovery. Dublin: The Ireland's Policy Advisory Board for Enterprise, Trade. Science, Technology and Innovation. Retrieved from https://library.ncirl.ie/items/28455

Freeman, R. E., \& Evan, W. M. (1990). Corporate governance: A stakeholder interpretation. Journal of behavioral economics, 19(4), 337-359. https://doi.org/10.1016/0090-5720(90)90022-Y

Grossi, G., Papenfuß, U., \& Tremblay, M. S. (2015). Corporate governance and accountability of state-owned enterprises: Relevance for science and society and interdisciplinary research perspectives. International Journal of Public Sector Management, 28(4/5), 274-285. https://doi.org/10.1108/IJPSM-09-2015-0166

He, Q. (1998). The Pitfalls of Modernisation: Economic and Social Problems in Contemporary China. Today China Publishing House: Beijing.

Hu, F., \& Leung, S. (2012). Appointment of politically connected top executives and subsequent firm performance and corporate governance: evidence from China's listed SOEs. In 2012 Financial Markets \& Corporate Governance Conference. https://doi.org/10.2139/ssrn.1979980

Huang, L. J., \& Snell, R. S. (2003). Turnaround, corruption and mediocrity: Leadership and governance in three state owned enterprises in Mainland China. Journal of Business Ethics, 43(1-2), 111-124. https://doi.org/10.1023/A:1022919418838

Jia, N., Huang, K. G., \& Man Zhang, C. (2019). Public governance, corporate governance, and firm innovation: An examination of state-owned enterprises. Academy of Management Journal, 62(1), 220-247. https://doi.org/10.5465/amj.2016.0543

Kesner, I. F., \& Dalton, D. R. (1985). The effect of board composition on CEO succession and organisational performance. Quarterly Journal of Business and Economics, 24(2), 3-20.

Khongmalai, O., Tang, J. C., \& Siengthai, S. (2010). Empirical evidence of corporate governance in Thai state-owned enterprises. Corporate Governance, 10(5), 17-634. https://doi.org/10.1108/14720701011085580

Kowalski, P., Büge, M., Sztajerowska, M., \& Egeland, M. (2013). State-owned enterprises: Trade effects and policy implications. OECD Trade Policy Papers No. 147, OECD Publishing, Paris.

Kwong, J. (1997). The Political Economy of Corruption in China. M.E. Sharpe, Inc.: New York.

Lin, C. (2001). Corporatisation and corporate governance in China's economic transition. 
Economics of planning, 34(1-2), 5-35. https://doi.org/10.1023/A:1017596315273

Mar, P., \& Young, M. N. (2001). Corporate governance in transition economies: A case study of two Chinese airlines. Journal of World Business, 36(3), 280-302. https://doi.org/10.1016/S1090-9516(01)00056-6

McGee, R. W. (2008). Corporate governance in transition economies. In Corporate Governance in Transition Economies (pp. 3-20). Springer, Boston, MA. https://doi.org/10.1007/978-0-387-84831-0_1

OECD. (2005). OECD Guidelines on Corporate Governance of State-owned Enterprises. Paris.

Parker, D. (1999). Regulation of privatised public utilities in the UK: performance and governance. International Journal of public sector management, 12(3), 213-35. https://doi.org/10.1108/09513559910267387

Peng, M. W., Buck, T., \& Filatotchev, I. (2003). Do outside directors and new managers help improve firm performance? An exploratory study in Russian privatisation. Journal of World Business, 38(4), 348-360. https://doi.org/10.1016/j.jwb.2003.08.020

Schwarting, G. (2013). Public corporate governance codes: necessary but successful too?. Administrative Culture, 14(1), 145-157.

Shih, C. Y. (1994). The Decline of a Moral Regime: China's Great Leap Forward in Retrospect. Comparative Political Studies, 27(2), 272-301. https://doi.org/10.1177/0010414094027002005

Simpson, S. N. Y. (2014). Boards and governance of state-owned enterprises. Corporate Governance, 14(2), 238-251. https://doi.org/10.1108/CG-08-2012-0063

Simpson, S. N. Y. (2014). Boards and governance of state-owned enterprises. Corporate Governance, 14(2), 238-251. https://doi.org/10.1108/CG-08-2012-0063

Snell, R. S. (2000). Studying moral ethos using an adapted Kohlbergian model. Organisation studies, 21(1), 267-295. https://doi.org/10.1177/0170840600211006

South African Institute of International Affairs (2014). Corporate Governance in Africa's State Owned Enterprises: Perspectives On An Evolving System. African Peer Review Mechanism (Aprm) Policy Briefing 102. Retrieved from Https://Media.Africaportal.Org/Documents/Saia_Spb_102_Corrigan_20140910.Pdf

Su, D., \& He, X. (2012). Ownership structure, corporate governance and productive efficiency in China. Journal of productivity analysis, 38(3), 303-318. https://doi.org/10.1007/s11123-011-0257-8

Sundaram, A. K., Bradley, M., Schipani, C. A., \& Walsh, J. P. (2000). Comparative corporate governance and global strategy (Ed.), In R.E. Grosse, Thunderbird on Global Business Strategy, John Wiley \& Sons, Inc, New York, pp. 110-150 
Syrett, S., \& Bertotti, M. (2012). Reconsidering private sector engagement in subnational economic governance. Environment and Planning A, 44(10), 2310-2326. https://doi.org/10.1068/a44675

Thomas, A. (2012). Governance at South African state-owned enterprises: what do annual reports and the print media tell us?. Social Responsibility Journal, 8(4), 448-470. https://doi.org/10.1108/17471111211272057

Wong, S. C. (2004). Improving corporate governance in SOEs: An integrated approach. Corporate Governance International, 7(2). Retrieved from https://ssrn.com/abstract=897121

Young, M. N., Ahlstrom, D., Bruton, G. D., \& Chan, E. S. (2001). The resource dependence, service and control functions of boards of directors in Hong Kong and Taiwanese firms. Asia Pacific Journal of Management, 18(2), 223-244. https://doi.org/10.1023/A:1010624109010

\section{Copyright Disclaimer}

Copyright for this article is retained by the author(s), with first publication rights granted to the journal.

This is an open-access article distributed under the terms and conditions of the Creative Commons Attribution license (http://creativecommons.org/licenses/by/4.0/). 